\title{
FROM NEGATIVE TO POSITIVE PEACE: \\ STRENGTHENING THE ROLE OF YOUTH IN RELIGIOUS \\ PEACEBUILDING IN BUKITTINGGI, WEST SUMATRA
}

\author{
Zulfan Taufik \\ State Islamic Institute of Bukittinggi \\ Kubang Putih, Agam, West Sumatera, Indonesia, 26181 \\ E-mail: zulfantaufik@iainbukittinggi.ac.id
}

\begin{tabular}{c|c|c}
\hline Received: & Revised: & Approved: \\
$03 / 06 / 2020$ & $05 / 10 / 2020$ & $05 / 10 / 2020$ \\
\hline
\end{tabular}

DOI: https:// doi.org/10.32332/akademika.v25i2.2132

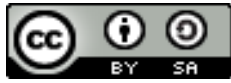

From Negative To Positive Peace: Strengthening The Role Of Youth In Religious Peacebuilding In Bukittinggi, West Sumatra Licensed Under a Creative Commons Attribution-ShareAlike 4.0 Internasional License

\begin{abstract}
Youth as religious peacebuilding actors still receive less attention in academic studies and peace praxis. It often makes youth being depicted as victims or as perpetrators of violence in religious conflict. This study specifically seeks to explore the efforts of youth involvement and also to strengthen the capacity of the youth in making religious peacebuilding in Bukittinggi, West Sumatra. By using the action research method, this research found that Bukittinggi is at negative peace, which is still at the level of mere absence of war and saving the seeds of mutual suspicion between interfaith believers. It is undoubtedly because of a lack of interaction and openness between the interfaith believers. As for the strengthening efforts are undertaken through interfaith youth forum, youth for peace workshop, and the initiation of the interfaith youth organization. That various efforts give hope for the future of religious peace in Bukittinggi from negative peace to positive peace. It is because youth offer creative energy and active potential to transform violent conflict and foster active peace.
\end{abstract}


Keywords: Youth, Religious Peacebuilding, Negative Peace, Positive Peace, Bukittinggi.

\section{A. Introduction}

The openness of youth to a variety of information has made them occupy the strategic positions in religious peacebulding efforts, as well as making them become vulnerable to religious intolerance and even radicalism and extremism. Such general conclusions can be found in various studies such as the Institute for Islamic Studies and Peace (2011), Maarif Institute $(2011)^{1}$, International NGO Forum on Indonesian Development $(2016)^{2}$, as well as the Center for The Study of Religion and Culture (2018) ${ }^{3}$.

Measuring the substantial potential that youth can play in embodying the nation's peacebuilding, as well as the potential of being used by those who want to spread destructive understanding, coaching and education need to be a common focus. Then, not less importantly, their involvement in growing as well as maintaining the values of peace in the community must be well recognized as a long-term social manifestation. ${ }^{4}$ Although most of the world's population is dominated by young people, attention is ironically rarely directed at this group.

Research and analysis of youth as actors of peace are still relatively minimal. It often makes youth being depicted as victims or as perpetrators of violence in conflict, as stated by Felice dan Wisler (2007) ${ }^{5}$, Mundal and

${ }^{1}$ Ahmad Fuad Fanani, "Fenomena Radikalisme Di Kalangan Kaum Muda," Maarif: Arus Pemikiran Islam dan Sosial 8, no. 1 (2013): 4-13.

2 Bagus Takwin et.al, Studi Tentang Toleransi Dan Radikalisme Di Indonesia: Pembelajaran Dari 4 Daerah Tasikmalaya, Jogjakarta, Bojonegoro Dan Kupang (Jakarta: International NGO Forum on Indonesian Development, 2016).

${ }^{3}$ Chaider S. Bamualim, at.al., Kaum Muda Muslim Milenial: Konservatisme, Hibriditas Identitas, Dan Tantangan Radikalisme (Tangerang Selatan: Center for The Study of Religion and Culture UIN Syarif Hidayatullah Jakarta, 2018).

4 Zulfan Taufik, "The Youth and The Primacy against Religious Radicalism through the Organization of Mahasiswa Ahlith Thariqah Al Mu'tabarah An Nahdliyyah (MATAN) in Indonesia," TEOSOFI: Jurnal Tasawuf dan Pemikiran Islam 9, no. 1 (June 1, 2019): 109-130, http://jurnalfuf.uinsby.ac.id/index.php/teosofi/article/view/248.

${ }_{5}^{5}$ Celina Del Felice and Andria Wisler, "The Unexplored Power and Potential of Youth as Peace-Builders," Journal of Peace Conflict \& Development, Issue, no. 11 (2007): 1-29. 
Cave (2007)6, McEvoy-Levy (2011)7, dan Huesca (2019) ${ }^{8}$. Youth may occupy various positions during and after the conflict. Youth can occupy the role of victim or perpetrator, simultaneously or alternately, or not both. However, such characterization also limits the framing of youth as potential peacebuilders. ${ }^{9}$

Some scholars, such as McEvoy (2010) ${ }^{10}$ and Leonard (2013) ${ }^{11}$, have highlighted the exclusion of youth from formal political practices and peace-building processes resulting in a limited representation of the voice of youth in this process. It because of age restrictions, but also partly because it underestimates the potential contribution of young people to positive peace-building through the political process.

In fact The role of youth as agents of peace often appears in various contexts in various parts of the world. ${ }^{12}$ Not all youths who are exposed to

${ }^{6}$ Lori Drummond-Mundal and Guy Cave, "Young Peacebuilders: Exploring Youth Engagement with Conflict and Social Change," Journal of Peacebuilding and Development 3, no. 3 (2007): 63-76.

7 Siobhán McEvoy-Levy, "Children, Youth and Peacebuilding," in Critical Issues in Peace and Conflict Studies: Theory, Practice and Pedagogy, ed. Thomas Matyok, Jessica Senehi, and Sean Byrne (Lanham, Maryland: Lexington Books, 2011), 159-176.

8 Eliisio F. Huesca, "On 'Youth, Peace, and Security' in Mindanao, Philippines," Peace Review 31, no. 1 (2019): 57-65, https://doi.org/10.1080/10402659.2019.1613597.

9 Valeria Izzi, "Just Keeping Them Busy? Youth Employment Projects as a Peacebuilding Tool," International Development Planning Review 35, no. 2 (2013): 103-117; Lesley J Pruitt, "Gendering the Study of Children and Youth in Peacebuilding," Peacebuilding 3, no. 2 (2015): 157-170.

10 Siobhán McEvoy, "Communities and Peace: Catholic Youth in Northern Ireland," Journal of Peace Research 37, no. 1 (2000): 85-103.

11 Madeleine Leonard, "Young People's Perspectives on Conflict, Reconciliation and Reunification in Cyprus," Children's Geographies 11, no. 3 (2013): 326-339.

12 Helen Berents and Siobhan McEvoy-Levy, "Theorising Youth and Everyday Peace(Building)," Peacebuilding 3, no. 2 (2015): 115-125; Steve Gillard, "Winning the Peace: Youth, Identity and Peacebuilding in Bosnia and Herzegovina," International Peacekeeping 8, no. 1 (2001): 77-98; Amani C. Kasherwa, "The Role of Youth Organizations in Peacebuilding in the African Great Lakes Region: A Rough Transition from Local and Non-Governmental to the National and Governmental Peacebuilding Efforts in Burundi and Eastern DRC'," Journal of Peace Education 17, no. 2 (2020): 123-160, https://doi.org/10.1080/17400201.2019.1688139; Angela J. Lederach, "Youth Provoking Peace: An Intersectional Approach to Territorial Peacebuilding in Colombia," Peacebuilding 8, no. 2 (2019): 198-217, 
conflict or who are in conflict victims' environments tend to conflict as well. Some of them are willing to develop peacebuilding programs, eliminate psychological trauma, and actively campaign for the need for peace. Some of them are also actively involved in the community to build mutual understanding and to try to understand the differences. All they do is not only to treat the wounds and remove the revenge but also as a serious effort to build harmony among people.

Even though critical attention has increased, the voices and experiences of youth are still far from being understood and accommodated, both in scientific studies and in peace praxis. The perspective and angle in this study provide an alternative to previous studies that viewed the youth as the victim of the radical acts carried out by adults as well as the victim of uncertain economic and political conditions. Therefore, this study specifically seeks to explore the efforts of youth involvement in peacebuilding initiatives with in Bukittinggi, West Sumatra.

In general, Bukittinggi is chosen because it is a town that has the highest population density in West Sumatra with a multireligious and multicultural community. Even though Bukittinggi in particular and West Sumatra in general are known to have conditions that are quite conducive, in the midst of this conducivity there are latent conflicts between religious groups due to the differences in interests. The religious cases and social cases of religious nuance that have occurred so far, which are actual and non-existent, prove that latent conflicts among religious community are quite intense..$^{13}$ In addition, this study also seeks to strengthen the capacity of the youth in making religious peacebuilding efforts. Above all, the author believes that young people have great potential in realizing peace building, including in religious peacebuilding

\section{B. Methodology}

The methodology used in conducting this study was action research. Action research consists of two words: action and research that are integrated. It explains the nature of research which considers that research and action are inseparable. Action or improvement is an integral part of action research. This kind of research is different from conventional research that aims to identify problems, analyze the causes, creates

https://doi.org/10.1080/21647259.2019.1616959; Bernando J. Sujibto, “Spirit Peacebuilding Melalui Komunitas Pemuda Di Yogyakarta," Jurnal Sosiologi Reflektif 10, no. 1 (2016): 273-302.

13 Bashori A Hakim, "Kerukunan Umat Beragama Di Sumatera Barat," Harmoni: Jurnal Multikultural dan Multireligius 11, no. 2 (2012): 102-115. 
explanations and implications of a phenomenon. ${ }^{14}$ Also, action research is applied research that emphasizes the interventions on social change rather than being limited to the formation of new theories.

As explained above about the action research model, this study began with an effort to map the conditions of religious peace and the youth potential in the efforts to build the peace between interfaith believers in Bukittinggi. The detailed stages of its activities are as follows:

1. In-depth interviews with government and religious leaders in Bukittinggi;

2. Focus group discussion with representatives of religious-based youth organizations in Bukittinggi;

3. Intervention in the form of strengthening knowledge and awareness of the values of peace, tolerance, the dangers of conflict and the prevention of violence and extremism through a workshop for representatives of religious-based youth organizations in Bukittinggi;

4. Intervention was also carried out in the form of discussions and giving understanding to religious leaders and stakeholders related to the role of youth and important place for these young people in efforts to create harmony. The intervention was also carried out in the form of direct involvement in FKUB (Forum for Religious Harmony) activities that involved youth such as futsal competitions and 'harmony' fun walks.

5. Reflection and revision of the results obtained.

The study involved various parties as follows: Forum for Religious Harmony Bukittinggi (FKUB), the Ministry of Religious Affair of Bukittinggi, the Indonesian Ulema Council of Bukittinggi (MUI) of Bukittinggi, the Ansor Youth Movement of Bukittinggi, Muhammadiyah Youth of Bukittinggi, Catholic Youth of Bukittinggi, Protestant Youth of Bukittinggi, Buddhist Youth of Bukittinggi, Islamic Students Association of Bukittinggi Branch (HMI), Indonesian Islamic Students Association of Bukittinggi Branch (PMII), Muhamadiyah Student Association of Bukittinggi Branch (IMM), Indonesian Muslim Students Association of Bukittinggi Branch (SEMMI), and Campus Da'wah Organization of IAIN Bukittinggi (LDK).

\section{The Condition of Religious Peace in Bukittinggi}

Bukittinggi is a multireligious and multiethnic town, which is not inhabited by many religious groups outside of Islam. However, when compared to 6 other towns/regencies in West Sumatra, Bukittinggi is a

14 Bridget Somekh, Action Research: A Methodology for Change and Development (Philadelphia: Open University Press, 2006), 8. 
town that is inhabited by many non-Muslims (3\%). ${ }^{15}$ The small number of non-Muslim population causes many homogeneous villages in terms of religion, namely Islam.

In term of ethnicity, besides Minangkabau as the dominant ethnic group, Bukittinggi is also inhabited by Chinese, Javanese, Tamil, and Batak ethnic groups. Chinese people came together with the emergence of markets in Bukittinggi. They were permitted by the Dutch East Indies government to build shops/stalls on the foothills of Fort de Kock Fort, which is located in the western part of thetown, stretching from south to north, and is now known as Kampung Cino. While Indian traders were placed in the northern foothills, circling from east to west and now is also called Kampung Keling. ${ }^{16}$

Regarding religious tolerance, SETARA Institute in the Tolerant City Index report which was released in 2018 mentioned Bukittinggi was in the red zone, which was the 83th out of 95 cities in Indonesia. ${ }^{17}$ This result was inversely proportional to the recognition of policy makers and religious leaders who consider that conditions of harmony and tolerance in Bukittinggi are in good and conducive condition. As the Chairperson FKUB of Bukittinggi stated as the following:

"Alhamdulillah in Bukittinggi there are no religious conflicts. There is indeed some friction, but we quickly overcome it. The friction often occurs precisely from the outside. For example, there were letters that went to the mosques around the HKBP church in Bukittinggi. But apparently it came from the Seksiovah "splinter sect", the Sect of Protestant Christians. Within Islam itself sometimes there are also minor conflicts such as the existence of Shia, but there is no a big conflict."18

15 BPS Provinsi Sumatera Barat, Provinsi Sumatera Barat Dalam Angka 2017 (Padang: BPS Provinsi Sumatera Barat, 2017), 286.

${ }^{16}$ Adlan Sanur Tarihoran, "Interaksi Antara Etnis Tionghoa Dan Masyarakat Lokal Dengan Pendekatan Multikulturalisme Di Kampung Cina Kota Bukittinggi," in Batusangkar International Conference 1 (Batusangkar: IAIN Batusangkar, 2016), 121-134.; Erniwati Erniwati, "Identitas Etnis Tionghoa Padang Masa Pemerintah Hindia Belanda," Patanjala: Jurnal Penelitian Sejarah dan Budaya 11, no. 2 (2019): 185.

17 Based on the index that measured the tolerant city through the local government regulation variable, social regulation, the local government action, and the demography of religion, Padang took place the 90th position, Payakumbuh the 84th position, Bukittinggi the 83rd, Pariaman 82nd, and Padang Panjang 78th of 94 cities/towns in Indonesia. Setara Institute, Ringkasan Eksekutif Indeks Kota Toleran Tahun 2018 (Jakarta: Setara Institute, 2018).

18Salman (the Chairperson FKUB of Bukittinggi), interview by author, Bukittinggi, August 3, 2018. 
The conducive religious life in Bukittinggi is also admitted by Catholic, Christian and Buddhist leaders.

"Good, relatively good here, as long as it is not provoked from outside parties. The arrival of lecturers from outside I think it is more wasteful than the benefits, because the contents I hear are provocative."19

"Religious harmony in Bukittinggi is quite good. Incidentally also because Christians or non-Muslims are only around $2 \%$ so it is also a factor in the lack of inter-religious upheavals in Bukittinggi. But in fact there had been a slight friction between Muslims and Protestants in particular. Because there is still a denomination in which some HKBP worshipers are still in homes. The form of conflict at that time, the Protestants held a group vocal training to prepare for Christmas at night at home. This was heard by the neighbors around the neighborhood and they felt disturbed because it was also almost ten o'clock at night. This conflict also reached the news. The exact location was housing complex in Ingkorba." 20

"During this time we see harmony in Bukittinggi is quite good, so for four years I am in Bukittinggi I feel quite comfortable. Maybe it is more comfortable than other places. We see that violence does not exist. Maybe there are pros and cons which are normal. ${ }^{21}$

From the interviews with several religious leaders who are also the board of FKUB Bukittinggi above, it can be concluded that Bukittinggi still has conflicts that are both inter-religious and intra-religious. Besides, the peaceful condition in Bukittinggi is still at the level of mere absence of war and saving the seeds of mutual suspicion between interfaith believers. This is certainly because of a lack of interaction and openness between the interfaith believers (dissociative). Even if there is an effort to create harmony and communication between interfaith believers, it still uses a top down strategy. Likewise at the level of policy which is still oriented to the elimination of direct violence, not the management of the causes of violence.

This condition, using Galtung's theory, is called negative peace. Galtung broadens the meaning of the concept of peace and violence to include indirect or structural violence, and this is a direct challenge to the

${ }^{19}$ Didik Trianto (Deputy Pastor of Chatolic in Bukittinggi and vice chairperson FKUB of Bukittinggi), interview by author, Bukittinggi, August 3, 2018.

${ }^{20} \mathrm{E}$. Nababan (Priest of HKBP Bukittinggi and vice chairperson FKUB of Bukittinggi), interview by author, Bukittinggi, August 3, 2018.

${ }^{21}$ Lani Viriya Bhumi (Pandita Buddha and member FKUB of Bukittinggi), interview by author, Bukittinggi, August 3, 2018. 
general idea of the nature of peace. The expansion of the concept of violence also affects the expansion of the concept of peace..$^{22}$

The main characteristics that can be summarized from Galtung's thoughts regarding negative peace are the absence of violence, pessimistic, curative, peace not always by peaceful means. Meanwhile, positive peace is structural integration, optimistic, preventive, peace by peaceful means. Likewise with what Clark revealed (2009) ${ }^{23}$, Shields (2017) ${ }^{24}$ and Gleditsch, Nordkvelle, and Strand $(2014)^{25}$ that negative peace characterized an absence of conflict, while positive peace characterized by reconciliation or integration.

In this negative peace condition in Bukittinggi, FKUB of Bukittinggi plays an important role in responding to and preventing the conflict from spreading and escalating.

It is like these small fires that can be overcome by FKUB. If there is a big conflict later, the government certainly will take over it. Like the conflict in the establishment of the Kartini Hotel which was right in front of the Nurul Haq Mosque mihrab. It was led to religious issues by extreme people, such as Zainudin. We conveyed that this was not a matter of religious conflict, but a matter of business conflict because there were many hotels there. It would be a religious conflict if the one that was built was a church. Therefore, so far indeed there have been sparks of conflict, but we quickly handled it. If the problem is in Catholicism, Catholic leader will find the solution. If it is in Christianity, the Christian pastors will solve it. Not us (from Muslims), because if we enter, it will become a conflict. ${ }^{26}$

The FKUB of Bukittinggi is indeed known as an enthusiastic and active FKUB in anticipating conflicts and divisions among religious

22 Johan Galtung, "An Editorial," Journal of Peace Research 1, no. 1 (1964): 1-4; Johan Galtung, "Violence, Peace, and Peace Research," Journal of Peace Research 6, no. $\quad 3$ (1969): $167-191, \quad$ https://www-jstororg.abc.cardiff.ac.uk/stable/422690?seq=1\#metadata_info_tab_contents; Johan Galtung, "Cultural Violence," Journal of Peace Research 27, no. 3 (1990): 291-305.

${ }^{23}$ Janine Natalya Clark, "From Negative to Positive Peace: The Case of Bosnia and Hercegovina," Journal of Human Rights 8, no. 4 (2009): 360-384.

${ }^{24}$ Patricia M Shields, "Limits of Negative Peace, Faces of Positive Peace," Parameters 47, no. 2 (2017): 5-14.

25 Nils Petter Gleditsch, Jonas Nordkvelle, and Håvard Strand, "Peace Research - Just the Study of War?," Journal of Peace Research 51, no. 2 (2014): 145158.

${ }^{26}$ Didik Trianto (Deputy Pastor of Chatolic in Bukittinggi and vice chairperson FKUB of Bukittinggi), interview by author, Bukittinggi, August 3, 2018. 
communities and carrying out various activities oriented towards the realization of religious harmony. Therefore, in 2017, FKUB of Bukittinggi was rewarded with the Harmony Awards. The award, which was directly given by the Minister of Religion Lukman Hakin Saifuddin, was given on the basis that the FKUB of Bukittinggi was considered as the most active FKUB in West Sumatra Province. ${ }^{27}$

Among the activities that are routinely carried out by the FKUB of Bukittinggi are as follows:

1. Carrying out a formal dialogue between religious or community leaders and certain forums such as gatherings, discussions, and two-way communication or informal daily meetings.

2. Opening up and accommodating the aspirations of social and religious organizations and the aspirations of the people and channeling these aspirations in the form of recommendations as a policy of the mayor of Bukittinggi.

3. Organizing the socialization of law regulations and policies in the field of religion related to religious harmony and community empowerment.

4. Providing written recommendations for the requests to establish places of worship after field surveys and requirements in accordance with applicable laws.

5. Holding regular meetings every month to discuss the issue of religious harmony as an effort to anticipate as early as possible the things that will interfere with harmony.

6. Conducting harmony activities such as: togetherness night, 'harmony' fun walks, interactive dialogues on local television such as BTV, TRI ARGA TV, comparative studies to several regions outside West Sumatra, providing socialization of Teaching and Learning Process (PBM) by printing pocket books on FKUB and question and answer about harmony and share it with stakeholders and the community.

7. Attending meetings and coordination with relevant agencies and other private institutions. ${ }^{28}$

Furthermore, the chairperson of FKUB of Bukittinggi said that there are various potentials that could disrupt religious harmony especially in Bukittinggi as follows:

27"FKUB Bukittinggi Raih Harmony Award Tahun 2017", https://m.minangkabau news.com/artikel-12234-fkub-bukittinggi-raih-harmonyaward-tahun-2017.html. Diakses pada 1 September 2018.

${ }^{28}$ Salman, Peran dan Urgensi Forum Kerukunan Umat Beragama (FKUB) dalam Menjaga Kerukunan Umat Beragama di Kota Bukittinggi, (Materi Workshop Youth for Peace: Peran Pemuda dalam Upaya Bina Damai Antar-Umat Beragama di Kota Bukittinggi, Bukittinggi, 27 Oktober 2018). 
1. A narrow understanding of the philosophy of "adat basandi syarak, syarak basandi kitabullah" for the Minang people.

2. People who are considered religious figures or religious leaders convey their intolerant preaching and fatwa and even tend to be inciting and provocative, from inside and outside Bukittinggi. A group claiming to be a community organization (organization) that fights for and defends religion and acts on behalf of the people of a particular religion in their own way tends to impose their opinions and desires with physical actions and violence which actually damage the image of the purity of the religion itself.

3. Accusing an activity and act carried out by certain religious people as if it is the teachings and orders of that religion, even though this is not so. it is due to the ignorance of the teachings of that religion.

4. Lack of understanding of the Joint Decree (SKB) of the Ministry of Religious Affairs and the Minister of Home Affairs, especially regarding the establishment of places of worship. ${ }^{29}$

The description above shows that the FKUB of Bukittinggi is quite active in the efforts to maintain and strengthen religious harmony. From the various activities carry out such as futsal competitions, fun walks, outbound, and "Togetherness Night" events, youth are also sometimes involved as participants. However, the involvement of young people in FKUB Bukittinggi activities is still limited to the object of the activities of the "old" administrators. After these activities, there is usually no follow up as a form of continuity of communication in maintaining harmony and cooperation between interfaith and intra-religious youth. For example, the inter-youth futsal competition activity that has been carried out routinely every year since 2016 has the aim that they can mingle with each other. But this is still a topdown which means that the youth only participate in activities or events held by FKUB. They have never had their own initiative in an effort to build peace in religious harmony in Bukittinggi. This is also due to the fact that non-Muslim youth in Bukittinggi are a minority.

Furthermore, in an effort to unite youth across religions in Bukittinggi FKUB has invited young representatives from every religion in the "Togetherness Night", in which FKUB hopes that the youth's role will be united in the efforts to build the religious harmony. However, this did not continue because of the inadequate communication between youths

${ }^{29}$ Salman, Peran dan Urgensi Forum Kerukunan Umat Beragama (FKUB) dalam Menjaga Kerukunan Umat Beragama di Kota Bukittinggi, (The material of Workshop Youth for Peace: Peran Pemuda dalam Upaya Bina Damai Antar-Umat Beragama di Kota Bukittinggi, Bukittinggi, 27 Oktober 2018). 
and there was no the youth who was willing or seemed enthusiastic to be a pioneer in building the religious harmony in Bukittinggi. ${ }^{30}$

Many factors play a role in the inactivity of young people in the efforts of building the religious harmony. One of the factors is such as the lack of non-Muslim youth in Bukittingi as well as the concerns of religious leaders (especially Islam) regarding the mission of non-Islamic religious mission, as stated in the following interview with the Chairman of FKUB:

From the activities of religious harmony which also involved many of its youth, then came the idea to create a youth forum among the interfaith believers. So in the future each activity will be held by them. FKUB will only direct and give the funding. But when I discussed the idea with the police during a conciliation rally about two years ago, the Chairman of MUI Bukittinggi and MUI Agam suggested not forming it because it can open the opportunities for non-Muslims to develop their mission. After I thought over it again, I became worried that the forum could trigger the conflicts later. ${ }^{31}$

However, in the process, the role of youth was less exposed. So far, the roles of conflict prevention and resolution are mostly carried out by older groups. The religious leaders and community leaders involved in the conflict resolution process were mostly dominated by people who were classified as senior. The less optimal of the role of youth in efforts to create religious harmony in Bukittinggi, among others, is due to the large number of community leaders who still doubt the ability of the youth. The young people are considered still not mature enough to solve various problems. Many people judge that adolescents, psychologically, are a group that is still unstable. They are still considered to have lack of experience. Their ego and emotions that are still not controlled well are considered as one of the factors triggering the occurrence of tension or friction among youth.

The negative stigma among young people, as shown in the description above, is also exacerbated by the notion that they have not played a significant role in peacebuilding activities. As a result, their potential is often underestimated in peacebuilding programs. Finally, many government policies related to peacebuilding efforts do not involve the youth. Most policy makers are more interested in seeing the youth as a problem rather than important potential in peacebuilding work. This is a

${ }^{30}$ Gazali (Head of Seksi Pendidikan Agama Islam Kantor Kemenag Kota Bukittinggi and Secretary FKUB of Bukittinggi), interview by author, Bukittinggi, Oktober 2, 2018.

31Salman (the Chairperson FKUB of Bukittinggi), interview by author, Bukittinggi, August 3, 2018. 
form of discrimination that is actually also a structural violence. The scholars critically remind: "The lack of children and youth participation in decision-making processes at all levels is also a form of structural violence. Decisions are often made for them, but not with them, loosing their valuable perspectives and insights." 32

\section{Strengthening the Positive Peace of Youth Environment}

Theoretically, the concept of peace is interpreted as a condition far from tension, conflict, and war. However, there are other meanings of peace that are not solely free from tension and war, but the conditions of mutual understanding and providing the others the opportunities for actualizing themselves, and the most important, ensuring justice. ${ }^{33}$ The different opinion such above arises two terms, namely true peace or positive peace and fake peace or negative peace. ${ }^{34}$ The positive peace is a condition in which the people can uphold the justice, respect the human rights, and eliminate the social discrimination. So it is not just about peace that is absent of social conflict. If there is a tension and a conflict, the citizens have the capacity to manage that social conflict so that it does not develop into violent conflict. Thus, the peacebuilding program does not take place incidentally, but takes place on an ongoing basis (sustainable).

The empowerment efforts undertaken through interfaith youth forums, youth for peace workshops, and the initiation of the Interfaith Youth Organization, as described below, open up the opportunities for a more positive level of peace among youth in Bukittinggi.

\section{Interfaith Youth Forum}

The Interfaith Youth Forum activity with young people from various religious-based youth communities in Bukittinggi was held on Saturday, October 6, 2018 on campus 2 of IAIN Bukittinggi. The main theme raised was "Exploring the Potential of Youth in the Efforts of Interfaith Peacebuilding in Bukittinggi". There were 13 participants attending, who were representatives of religious-based youth organizations in Bukittinggi, namely: Muhammadiyah Youth, GP Ansor, Catholic Youth, Naposo HKBP, Buddhist Youth, HMI, SEMMI, and LDK IAIN Bukittinggi. There were not many invited participants, but they represented a variety of religious-based

32 Felice and Wisler, "The Unexplored Power and Potential of Youth as Peace-Builders."

33 David Cortright, Peace: A History of Movements and Ideas (Cambridge: Cambridge University Press, 2008), 6-7.

34 Galtung, "An Editorial"; Irfan Abubakar, "Menuju Paradigma Peacebuilding Pascakonflik Kekerasan," Jurnal Tashwirul Afkar, no. 22 (2007): 26-40. 
youth organizations in Bukittinggi. It was also intended that the discussion could be more directed and in-depth.

The participants conveyed many things in the forum. They were related to the complaints about the conditions faced in the context of religious harmony in Bukittinggi, the hopes for change for the better, and the concrete steps that could be played by young people. For example, Iqbal Vernanwinata, who represented HMI of Bukittinggi Branch, said that one of the things that made the condition of religious harmony in Bukittinggi was due to the overly dominant Muslim population reaching more than $97 \%$. But it also made interaction between interfaith believers become very minimal. He even admitted that it was only at this forum that he could meet friends from Catholic and Buddhist youth. Therefore, he hoped that meetings like this could be more intensely held. In addition, social media and music, which are closely linked to millennial youth, can be a vehicle for these interactions. 35

A similar sentiment was also conveyed by Simon, the chairperson of Catholic Youth Bukittinggi. He believed that the conditions of religious life in Bukittinggi were still very harmonious so far. However, it was still an individual way. It meant that intensive communication has not yet been established. Even if there was intensive communication, it only happened at a high level, not touching the society. Based on his experience of attending school and socializing in Bukittinggi, he felt that there were still very many barriers among young people of different religions. Both those from Catholics and Muslims still seemed reluctant to open up and establish communication. Therefore, he highly appreciated the activity which in his observations was the first meeting particularly for youth. Even if there had been an activity from FKUB that also involved young people, he felt that it was only a formality. Because it has not yet touched the level of building intense communication and friendship that were truly intimate between interfaith believers in Bukittinggi. ${ }^{36}$

A. Haris Suhada, who represented the Muhammadiyah Youth, said that activities such as the Youth Interfaith Forum embraced young people who did not yet know each other to get acquainted and establish friendship. Therefore, in this moment there should be an official forum and management of a youth interfaith forum. In that forum, all representatives of religions or youth organizations could take part. So that later it will be

${ }^{35}$ Iqbal Vernanwinata (Chairperson of HMI Branch Bukittinggi), Focused Group Discussin in Youth Interfaith Forum, at IAIN Bukittinggi, October 6, 2018.

36Simon Bernand (Chairperson of Catholic Youth), Focused Group Discussin in Youth Interfaith Forum, at IAIN Bukittinggi, October 6, 2018. 
easy to communicate and organize activities together. In addition, he also deemed it necessary to utilize social media in building networks and facilitating communication. For example, if there are activities within each religion, it can be easily shared or invite if possible. ${ }^{37}$

According to Huzil Afwa, who was the chairperson of the Muhammadiyah Student Association, unfortunately, the role of youth was not visible in the efforts of religious harmony in Bukittinggi. At the same time, the elderly were very agile in creating harmony. From this arises a question, whether the young people were lacking of awareness or the old people did not optimally accommodate young people to be able to contribute in creating religious harmony. He further believed that it could be that the young people were lacking of the awareness, for example, the absence of youth interfaith institutions themselves or organizations on behalf of youth in the context of religious harmony. That should be what we needed to create first. ${ }^{38}$

Megayani Sitorus, spiritual adviser of Batak Protestant Christian Huriyah Youth (HKBP), said that activities like this were very important to be carried out, especially for young people, young women, and coaches to accommodate various existing problems. This is where we can meet and get acquainted with young people from various religious communities. ${ }^{39}$

Critical voices and solutions of interfaith youth in Bukittinggi regarding the condition of religious harmony and the absence of a role they can play in building peace are critical. Given that the youth theoretically have an essential role in promoting peaceful social change. Focusing solely on their vulnerability is a perspective that limits and denies their opportunity to influence their own lives and futures, neglecting their insights, their right to participate, and their potential to contribute to peacebuilding. 40

${ }^{37}$ A. Haris Suhada (Secretary of Pemuda Muhammadiyah Bukittinggi), Focused Group Discussin in Youth Interfaith Forum, at IAIN Bukittinggi, October 6, 2018.

${ }^{38} \mathrm{Huzil}$ Afwa (Chairperson of the Muhammadiyah Student Association /IMM), Focused Group Discussin in Youth Interfaith Forum, at IAIN Bukittinggi, October 6, 2018.

${ }^{39}$ Megayani Sitorus (Spiritual adviser of Batak Protestant Christian Huriyah Youth/HKBP Bukittinggi), Focused Group Discussin in Youth Interfaith Forum, at IAIN Bukittinggi, October 6, 2018.

40 Drummond-Mundal and Cave, "Young Peacebuilders: Exploring Youth Engagement with Conflict and Social Change"; Felice and Wisler, "The Unexplored Power and Potential of Youth as Peace-Builders." 
From the various ideas, an important outcome which was then agreed upon by the participants was that a forum was needed to meet the interfaith youths. So as a follow-up and initial step, a Whatsapp Group was formed under the name "Interfaith Youth Forum" which contained participants who attended the Interfaith Youth Forum.

\section{Youth for Peace Workshop}

As a follow up to the various suggestions and input put forward by the participants in the Interfaith Youth Forum activity above, a workshop was held which aimed at strengthening the understanding and role of youth in efforts to build peace between interfaith believers. This activity was held on Saturday, October 27, 2018, at 08.00 - 12.30 at the Teras Kota Café and Resto Bukittinggi, which was attended by 26 youths from a religious-based youth organization in Bukittinggi. The youth organization attended that meeting such as Muhammadiyah Youth, GP Ansor, Catholic Youth, HKBP Youth, Buddhist Youth, HMI, PMII, SEMMI, and LDK IAIN Bukittinggi

The speakers and the material presented in the workshop are as follows

a. Drs. H. Salman, MH: the chairperson FKUB of Bukittinggi. The material presented was about the Role and Function of FKUB in Maintaining Religious Harmony in Bukittinggi.

b. Dr. Sefriyono, M.Pd: Lecturer in Religion Studies of Imam Bonjol State Islamic University Padang. The material presented was Arranging the Reasoning for Diversity for Strengthening National Identity.

This activity is an integral part of peace education for interfaith youth in Bukittinggi. Education for peace raises dialogue on critical issues in the hearts of the people in order to transform an oppressive system from a violent orientation to a culture of peace. Thus, through education for peace, educators and students critically discuss the manifestations of, and justifications for, violence, identify the actors involved and the goals of a peaceful future. ${ }^{41}$

\section{The Establishment of Bukittinggi Interfaith Youth Organization}

After going through the stages of brainstorming through Interfaith Youth Forum and Youth for Peace Workshop, the next important thing and the main target was the establishment of an official organization covering

41 Kevin Kester, "Education for Peace: Content, Form, and Structure Mobilizing Youth for Civic Engagement," Peace E Conflict Review 4, no. 2 (2010): 110 . 
the interfaith youth in Bukittinggi. Although on several occasions, religious leaders and young people are very enthusiastic about the idea of the interfaith youth organization, but at the realization level it is not easy to embody it. Some obstacles that arise are as follows:

a. The fear of rejection by some groups who consider that this interfaith youth organization will actually be the cause of damage to harmony that has existed so far. In addition, they are also worried that forums like this will give the opportunity for other religions (besides Islam) to grow in Bukittinggi.

b. The Youth confusion to determine the institutional status of the organization whether it is under FKUB or independent.

c. Young people who are less interested and active in in harmony issues.

The obstacles encountered above were tried to be solved together through various follow-up discussions with various parties as well as asking for moral support so that this interfaith youth organization could be realized. It can be seen from the meeting conducted by the chairman of MUI of Bukittinggi, the chairman of Muhammadiyah of Bukittinggi Branch, and the chairman of NU of Bukittinggi Branch.

From the results of the discussion, it was seen that the leaders of Islamic community organizations greatly appreciated the idea of the establishment of interfaith youth organization and hoped that the organization could be a good forum for maintaining the harmony among the religious community in Bukittinggi which had been known to be very conducive.

The follow-up meeting was also held by the leaders of interfaith believers in FKUB. The leaders of interfaith believers were also very open and encouraged the youth to establish a organization that can bring them together. Only indeed, FKUB itself does not have the authority to provide a organization under their management so that the most possible thing to do is to establish an independent youth organization. The relationship of FKUB towards that independent youth organization is only limited as a director. As a concrete first step in encouraging the youth, Buya Salman as the Chairman of FKUB allowed the youth to use the FKUB secretariat as their meeting room if needed. Furthermore, the representatives of the youths were also directly involved in the committee on the event for the fun walk for the harmony of the interfaith believers in Bukittinggi held by FKUB on December 15, 2018.

Recognition of the capacity of youth and the opportunity to be involved in religious peacebuilding through the formation of an interfaith youth organization can erase the stigma about youth who are vulnerable to 
violence. ${ }^{42}$ The existence of this organization is also expected to be able to fill the void of youth in making policies related to religious peace, especially those related to youth.

\section{E. Conclusion}

The peaceful condition in Bukittinggi is is at negative peace, which is still at the level of mere absence of war and saving the seeds of mutual suspicion between interfaith believers. It is undoubtedly because of a lack of interaction and openness between the interfaith believers. Even if there is an effort to create harmony and communication between interfaith believers, it still uses a top down strategy. Likewise at the level of policy which is still oriented to the elimination of direct violence, not the management of the causes of violence.

Various efforts to strengthen and involve youth in religious peace initiatives give hope for the future of religious peace in Bukittinggi from negative peace to positive peace. It is because youth offer creative energy and active potential to transform violent conflict and foster active peace. The empowerment efforts are undertaken through the interfaith youth forum, youth for peace workshop, and the initiation of the interfaith youth organization have made the hope of this research-based community service can be achieved, namely:

1. The spread of knowledge and awareness of the values of peace, tolerance, the danger of conflict and prevention of violence and extremism among the youth of interfaith believers in Bukittinggi,

2. The increased understanding and ability to promote the value of peace and peacebuilding among the youth interfaith believers in Bukittinggi;

3. The existence of "agent of peace" in the religious-based youth organizations in Bukittinggi;

4. The existence of interfaith youth organization in Bukittinggi.

The youth also need to be allowed to be actively involved and participate in peacebuilding. Involving the youth to embody the peace will positively contribute to the forming of a generation that cares for peace and is ready to resist violence. Moreover, in the hands of the youth, the peacebuilding program can be done creatively and fun [.]

\section{REFERENCES}

Abubakar, Irfan. "Menuju Paradigma Peacebuilding Pascakonflik

42 Felice and Wisler, "The Unexplored Power and Potential of Youth as Peace-Builders." 
Kekerasan." Jurnal Tashwirul Afkar, no. 22 (2007): 26-40.

Bamualim, at.al., Chaider S. Kaum Muda Muslim Milenial: Konservatisme,

Hibriditas Identitas, Dan Tantangan Radikalisme. Tangerang Selatan:

Center for The Study of Religion and Culture UIN Syarif Hidayatullah Jakarta, 2018.

Barat, BPS Provinsi Sumatera. Provinsi Sumatera Barat Dalam Angka 2017. Padang: BPS Provinsi Sumatera Barat, 2017.

Berents, Helen, and Siobhan McEvoy-Levy. "Theorising Youth and Everyday Peace(Building)." Peacebuilding 3, no. 2 (2015): 115-125.

Bukittinggi, BPS Kota. Kota Bukittinggi Dalam Angka. Bukittinggi: BPS Kota Bukittinggi, 2018.

Clark, Janine Natalya. "From Negative to Positive Peace: The Case of Bosnia and Hercegovina." Journal of Human Rights 8, no. 4 (2009): 360384.

Cortright, David. Peace: A History of Movements and Ideas. Cambridge: Cambridge University Press, 2008.

Drummond-Mundal, Lori, and Guy Cave. "Young Peacebuilders: Exploring Youth Engagement with Conflict and Social Change." Journal of Peacebuilding and Development 3, no. 3 (2007): 63-76.

Erniwati, Erniwati. "Identitas Etnis Tionghoa Padang Masa Pemerintah Hindia Belanda." Patanjala: Jurnal Penelitian Sejarah dan Budaya 11, no. 2 (2019): 185.

Fanani, Ahmad Fuad. "Fenomena Radikalisme Di Kalangan Kaum Muda." Maarif: Arus Pemikiran Islam dan Sosial 8, no. 1 (2013): 4-13.

Felice, Celina Del, and Andria Wisler. "The Unexplored Power and Potential of Youth as Peace-Builders." Journal of Peace Conflict $\mathcal{E}$ Development, Issue, no. 11 (2007): 1-29.

Galtung, Johan. “An Editorial." Journal of Peace Research 1, no. 1 (1964): 1-4.

- - - "Cultural Violence." Journal of Peace Research 27, no. 3 (1990): 291305.

- - -. "Violence, Peace, and Peace Research." Journal of Peace Research 6, no. 3 (1969): 167-191. https://www-jstororg.abc.cardiff.ac.uk/stable/422690?seq=1\#metadata_info_tab_conte nts.

Gillard, Steve. "Winning the Peace: Youth, Identity and Peacebuilding in Bosnia and Herzegovina." International Peacekeeping 8, no. 1 (2001): 77-98.

Gleditsch, Nils Petter, Jonas Nordkvelle, and Håvard Strand. "Peace Research - Just the Study of War?" Journal of Peace Research 51, no. 2 (2014): 145-158.

Hakim, Bashori A. "Kerukunan Umat Beragama Di Sumatera Barat." 
Harmoni: Jurnal Multikultural dan Multireligius 11, no. 2 (2012): 102115.

Huesca, Eliisio F. "On 'Youth, Peace, and Security' in Mindanao, Philippines." Peace Review 31, no. 1 (2019): 57-65. https://doi.org/10.1080/10402659.2019.1613597.

Izzi, Valeria. "Just Keeping Them Busy? Youth Employment Projects as a Peacebuilding Tool." International Development Planning Review 35, no. 2 (2013): 103-117.

Kasherwa, Amani C. "The Role of Youth Organizations in Peacebuilding in the African Great Lakes Region: A Rough Transition from Local and Non-Governmental to the National and Governmental Peacebuilding Efforts in Burundi and Eastern DRC'." Journal of Peace Education 17, no. 2 (2020): 123-160. https://doi.org/10.1080/17400201.2019.1688139.

Kester, Kevin. "Education for Peace: Content, Form, and Structure Mobilizing Youth for Civic Engagement." Peace \& Conflict Review 4, no. 2 (2010): 1-10.

Lederach, Angela J. "Youth Provoking Peace: An Intersectional Approach to Territorial Peacebuilding in Colombia." Peacebuilding 8, no. 2 (2019): 198-217. https://doi.org/10.1080/21647259.2019.1616959.

Leonard, Madeleine. "Young People's Perspectives on Conflict, Reconciliation and Reunification in Cyprus." Children's Geographies 11, no. 3 (2013): 326-339.

McEvoy-Levy, Siobhán. "Children, Youth and Peacebuilding." In Critical Issues in Peace and Conflict Studies: Theory, Practice and Pedagogy, edited by Thomas Matyok, Jessica Senehi, and Sean Byrne, 159-176. Lanham, Maryland: Lexington Books, 2011.

McEvoy, Siobhán. "Communities and Peace: Catholic Youth in Northern Ireland." Journal of Peace Research 37, no. 1 (2000): 85-103.

Pruitt, Lesley J. "Gendering the Study of Children and Youth in Peacebuilding." Peacebuilding 3, no. 2 (2015): 157-170.

Setara Institute. Ringkasan Eksekutif Indeks Kota Toleran Tahun 2018. Jakarta: Setara Institute, 2018.

Shields, Patricia M. "Limits of Negative Peace, Faces of Positive Peace." Parameters 47, no. 2 (2017): 5-14.

Somekh, Bridget. Action Research: A Methodology for Change and Development. Philadelphia: Open University Press, 2006.

Sujibto, Bernando J. "Spirit Peacebuilding Melalui Komunitas Pemuda Di Yogyakarta." Jurnal Sosiologi Reflektif 10, no. 1 (2016): 273-302.

Takwin, Bagus. et.al. Studi Tentang Toleransi Dan Radikalisme Di Indonesia: Pembelajaran Dari 4 Daerah Tasikmalaya, Jogjakarta, Bojonegoro Dan 
Kupang. Jakarta: International NGO Forum on Indonesian Development, 2016.

Tarihoran, Adlan Sanur. "Interaksi Antara Etnis Tionghoa Dan Masyarakat Lokal Dengan Pendekatan Multikulturalisme Di Kampung Cina Kota Bukittinggi." In Batusangkar International Conference 1, 121-134. Batusangkar: IAIN Batusangkar, 2016.

Taufik, Zulfan. "The Youth and The Primacy against Religious Radicalism through the Organization of Mahasiswa Ahlith Thariqah Al Mu'tabarah An Nahdliyyah (MATAN) in Indonesia." TEOSOFI: Jurnal Tasawuf dan Pemikiran Islam 9, no. 1 (June 1, 2019): 109-130. http://jurnalfuf.uinsby.ac.id/index.php/teosofi/article/view/248.

\section{Interviews:}

Afwa, Huzil. (Chairperson of the Muhammadiyah Student Association/IMM). Focused Group Discussin in Youth Interfaith Forum, at IAIN Bukittinggi, October 6, 2018.

Bernand, Simon (Chairperson of Catholic Youth). Focused Group Discussin in Youth Interfaith Forum, at IAIN Bukittinggi, October 6, 2018.

Bhumi, Lani Viriya (Pandita Buddha and member FKUB of Bukittinggi). Interview by author, Bukittinggi, August 3, 2018.

Gazali (Head of Seksi Pendidikan Agama Islam Kantor Kemenag Kota Bukittinggi and Secretary FKUB of Bukittinggi). Interview by author, Bukittinggi, Oktober 2, 2018.

Nababan, E. (Priest of HKBP Bukittinggi and vice chairperson FKUB of Bukittinggi). Interview by author, Bukittinggi, August 3, 2018.

Salman (the Chairperson FKUB of Bukittinggi). Interview by author, Bukittinggi, August 3, 2018.

Sitorus, Megayani (Spiritual adviser of Batak Protestant Christian Huriyah Youth/HKBP Bukittinggi). Focused Group Discussin in Youth Interfaith Forum, at IAIN Bukittinggi, October 6, 2018.

Suhada, A. Haris (Secretary of Pemuda Muhammadiyah Bukittinggi). Focused Group Discussin in Youth Interfaith Forum, at IAIN Bukittinggi, October 6, 2018.

Trianto, Didik (Deputy Pastor of Chatolic in Bukittinggi and vice chairperson FKUB of Bukittinggi). Interview by author, Bukittinggi, August 3, 2018.

Vernanwinata, Iqbal (Chairperson of HMI Branch Bukittinggi). Focused Group Discussin in Youth Interfaith Forum, at IAIN Bukittinggi, October 6, 2018. 